\title{
KALVDYRKARNAS AVKOMLINGAR I KORSDRAGET MELLAN DET FÖR- FLUTNA OCH SAMTIDENS UTMANINGAR
}

\author{
Pekka Lindevist \\ Abo

De säger till Israel: "Ett folk som vid Sinaiberget hörde från sin Guds mun: 'Du skall inga andra gudar ha vid sidan av mig.' och efter fyrtio dagar sade om en kalv: 'Detta är din Gud, Israel.' - finns det en frälsning för detta?"

\section{INLEDNING}

De episoder i det förflutna vilka känns pinsamma möts på olika sätt. Att tiga ihjäl, Todschweigen, är ett sätt. Ett annat är att tyda det skedda till det bästa genom en omtolkning av detaljerna, faktorerna i spelet eller kontexten. ${ }^{1}$ Människor, grupper och folk blir tvungna till uppgörelse med det förflutna. Detta sker eftersom de bär den egna historien med sig och livets gång, t.ex. religionsurövning, övrig kultur eller historiens omvälvningar oundvikligen och upprepat leder dem till ett möte med den. Även samtiden kan börja ställa frågor som tvingar till konfrontation med historien. Det är inte sällsynt att utanförstående betraktares fingrar pekar på skamfläckar i det förflutna. Med andra ord: mötet sker då man konfronteras med utmaningar från minnen eller från samtiden.

Översatt till midrashforskningens språk och klätt i ord av Geza Vermes skulle teoremet lyda: Konfrontationen med en ny situation - t.ex. behovet att förklara en ny situation som samfundet har hamnat i - leder till tillämpad 
exeges medan konfrontationen med svårigheter, spänningar och luckor i själva den bibliska texten ger upphov till ren exeges. ${ }^{2}$ Trots att resultat kan vara identiska är upphoven till exegesen olika. I det första fallet ställer den historiska kontexten i en viss kontext frågorna och med dessa frågor vänder man sig till texten. I det sistnämnda fallet är textens karaktär själva upphovet.

I den här artikeln är den pinsamma historiska episoden den bibliska berättelsen om guldkalven, de som konfronteras med denna är tidiga judar, först och främst rabbiner och med samtiden syftas på talmudperioden. I de rabbinska skrifterna möter vi kalvepisoden å ena sidan tolkad "naturligt" som en synd par excellence men å andra sidan fäster mångahanda omtolkningar som mer eller mindre relativiserar avfallets allvar samt försök att undvika onödiga påminnelser av det skedda uppmärksamheten. Av dessa två principiella attityder - att acceptera eller att skönmålande omtolka historien - är den sistnämnda av ett speciellt intresse. Den är det klart dominerande sättet att behandla den ifrågavarande episoden i den tidiga judendomen och den väcker frågan om faktorerna bakom den. Vill man ge ett namn till denna attityd torde apologetisk vara mest täckande. Vill man ge ett namn till den approachen som söker efter faktorer bakom den apologetiska inställningen torde konfrontationskritisk vara den starkaste kandidaten. ${ }^{3}$

Den rabbinska apologetiska tolkningen av kalvepisoden är fängslande inte minst därför att genom den har man tänkt sig kunna skåda in i den judiskkristna konfrontationen under de första århundradena. Två banbrytande studier under de senaste årtionden har betonat den här aspekten starkt - och i stort sett förbisett andra aspekter. Den första av dessa var skriven av Arthur Marmorstein i 1935 (Judaism and Christianity in the middle of the third century ${ }^{4}$ ) och den andra av Leivy Smolar och Moshe Aberbach i 1968 (The golden calf episode in postbiblical literature). De är av ett grundläggande värde men måste läsas med ett kritiskt öga. Enligt Marmorstein kan man i rabbinska utsagor, vilka han utgående från rabbinernas namn daterar till 200-talet se ett belägg för en aggressiv judisk-kristen konfrontation som kulminerar under det ifrågavarande århundradet. Problemet med Marmorsteins tankegång är att i själva verket förmedlar hans omfattande samling av judiska utsagor om kalvepisoden för en nutida, kritisk läsare inte alls den bild som författaren har haft för avsikt att ge. I stället för rubrikens mycket exakta tidsbestämning "i mitten av det tredje århundradet" borde man snarare tala om "under det första årtusendet" - så omfattande är nämligen den tidsperiod som representeras av de skriftliga källorna som författaren åberopar. Artikeln lider också av en hel del axiomatiska, ur den kritiska läsarens synvinkel överdrivna, påståenden, vars hållbarhet inte alls diskuteras. ${ }^{5}$

Det huvudsakliga problemet med Smolar \& Aberbachs studie, i vilken författarna strävar efter att ge en täckande bild över tolkningen av kalvepisoden 
under den efterbibliska tiden, är att den ifrågavarande ca. 600 års period betraktas som en enhetlig rabbinsk period och författarna ser knappast något behov av hänvisning till historisk utveckling under epoken. Inget under att de känner sig tvungna att konstatera: "the rabbinic reaction (...) was anything but consistent". 6

Nuförtiden, då man inom forskningen på många punkter har tagit avstånd från alltför långt drivna generaliseringar i stilen "rabbinsk syn på" kan man även i frågan om attityden till kalvepisoden sträva efter en noggrannare tecknad karta. Det finns utveckling och det visar sig följa förklarliga linjer. Till den här slutsatsen - till vilken jag har fått bekräftelse efter att själv ha fattat bekantskap med den tidiga judiska tolkningen av den ifrågavarande episoden $^{7}$ - har jag ursprungligen blivit anvisat av det enkla resultatet av en studie av Irving J. Mandelbaum. Han visar i sin metodologiskt följdriktiga artikel Tannaitic exegesis of the Golden Calf episode från 1990 att under den tannaitiska perioden hade man en enstämmig inställning till kalvepisoden: Den apologetiska exegesen lyser med sin frånvaro. Ökengenerationens enda försvar är att de fick förlåtelse. Till den här slutsatsen kommer man när man konsekvent analyserar traditioner enbart i de tannaitiska textkällorna. ${ }^{8}$ Det här betyder att Smolar \& Aberbachs uppfattning om den allmänna bilden av den rabbinska perioden måste omvärderas. Om den apologetiska attityden å ena sidan är den tydligt dominerande under den rabbinska tiden men å andra sidan praktiskt taget saknas i tannaitiska källor betyder detta förstås att i övriga källor borde man konfronteras med ett svall av tolkningar med den här nyansen. Apologetiskt färgade drag kan ses redan under det första århundradet hos Filon och Pseudo-Filon. Särskilt hos Pseudo-Filon ${ }^{9}$ möter man midrashtolkningar som senare på nytt dyker upp i rabbinsk tradition. Inom den rabbinska litteraturens ramar sker frammarschen av den apologetiska exegesen i de sk. amoraitiska källorna. Ett framvällande av vissa slags tolkningar i bestämda historiska skeden lockar oss förstås att fråga efter faktorerna bakom ett sådant fenomen. Vi skall i den här artikeln lämna en närmare betraktelse av första århundradets texter åsido men ur dessa källor ändå ösa det grundläggande antagandet att all apologetisk midrash med säkerhet inte kan vara inspirerad av den kristna polemiken.

\section{SKANDALEN MED KALVEN}

Den gammaltestamentliga bilden är klar och entydig: dom över kalvdyrkarna. Ökengenerationens avfall möts med ett starkt ogillande i alla texter, dvs. Ex 32, Deut 9,7-2I, Neh 9,I8 och Ps 106,19-23, vilka på något sätt tangerar kalvdyrkan. Det olyckliga intermezzot vid Sinai står i nära samband med frågan 
om förbundet mellan Gud och Israel. Det unika historiska sammanhanget och det med avfallet förknippade hotet om folkets förintelse accentuerar berättelsens tyngd. Denna emotionella laddning tillsammans med en sparsam beskrivning, mångtydiga detaljer till följd av det förstnämnda samt de bibliska hjältarnas uppseendeväckande agerande gör episoden till ett utomordentligt objekt för senare tolkning - och det har den varit både inom den judiska och den kristna tolkningstraditionen. Den dominerande tonen i all tolkning av kalvepisoden efter Gamla testamentet är i grunden negativ i den bemärkelsen att episoden anses, implicit eller explicit, ha varit skadlig för Israels gudsrelation och ur judisk synvinkel således även misskrediterande för folket. Detta förtretliga element var man ändå tvungen att konfronteras med inom judendomen: Det var en oskiljaktig del av folkets historia och Toran som man var förpliktad att lära vidare och läsa upp i synagogan. På tal om t.ex. ett så centralt motiv som Lagens mottagande på Sinai blev man samtidigt så gott som oundvikligen påmind om folkets avfall vid foten av berget. Man kunde säga att guldkalven på detta sätt kastade sin skugga över den mest centrala fasen i folkets historia. Berättelsen kunde helt enkelt inte ha förbigåtts med tystnad - den krävde en reaktion.

$\AA$ ena sidan tycks den gammaltestamentliga texten i detta specifika fall och den oeftergivliga principen att Guds välvilja mot sitt folk är beroende av folkets trohet inte, åtminstone vid första blicken, lämna mycket spelrum för utläggarna. $\AA$ andra sidan - om texten tycks innehålla någonting dunkelt kan en utläggare som inte nöjer sig med att stanna vid textens explicita budskap börja gräva fram skikt som vid första blicken inte var synliga. Resultat av en sådan process möter man överallt i den tidiga judiska litteraturen.

Det kan vara belysande att betrakta kalvepisoden i ljuset av midrashbildningens allmänna lagbundenheter. G. Vermes skiljer i bibeltexterna mellan fyra egenskaper som leder till den typen av midrash han kallar för ren exeges: I) ett textavsnitt innehåller uttryck vars exakta innebörd inte är klar för utläggaren, 2) ett textavsnitt tycks strida mot andra bibliska texter, 3) beskrivningen i ett textavsnitt är inte tillräcklig detaljerad, och 4) ett textavsnitts uppenbara innehåll kan inte accepteras. ${ }^{10}$ Praktiskt taget hela Vermes' karakterisering konkretiseras i de pentateukiska beskrivningarna av kalvepisoden.

Då berättelsens innehåll känns pinsamt kan den som t.ex. känner sig emotionellt bunden till någon av dramats parter börja söka nya synvinklar eller olika förklaringar till det skedda. Det behövs ingen yttre impuls för att avkomlingar skulle känna behovet att tyda det som fäderna gjorde till det bästa. För det andra förekommer det i kalvepisoden luckor och oklarheter som en utläggare väl kan ta fasta på. Dessa luckor i berättelsen - ofullständiga beskrivningar eller tvetydiga uttryck - gör det möjligt för den kreativa rabbin- 
ska bibeltolkningen att "se bakom texten" och där hitta nya, tidigare dolda, dimensioner. Den outtömmande och svårtolkade beskrivningen väcker frågor som torde vara helt begripliga även för en nutida bibelläsare: Vad fick folket att avfalla så plötsligt? Varför gick Aron med på folkets krav utan tvekan? Vad upplevde Aron som förmådde honom att bygga ett altare (Ex 32,5 säger nämligen ordagrannt וירא אהרץ ויבץ, "och Aron såg och byggde") - folkets jubelrop bevarat i den föregående versen eller någonting annat som vi inte informeras om? Varför framställde Aron kalvstoden själv fast han säkert hade hundratals entusiastiska arbetsmän omkring sig? Varför utlyste han festen först för följande dagen? Hur tillkom kalven? Fanns det faktiskt någonting övernaturligt med i spelet, såsom bibeltexten tycks antyda (v.24)? I vilken mån ligger skulden hos hela folket som stod vid Sinaiberget - de som slogs ihjäl var ju endast en bråkdel av folket? Till sådana frågor ser vi den tidiga judendomen ge svar.

Omtolkning blir nödvändig även då ett textavsnitt tycks strida mot andra bibliska texter. Medan midrashen ofta ägnar sig åt att harmonisera detaljbeskrivningar som är svåra att förknippa med övrig information är kalvepisodens dissonans med den övriga sakrala historien på en mer övergripande nivå. ${ }^{11}$ Problemet ligger i spänningen mellan avfallets radikalitet och Förbundets fortbestånd trots det skedda samt i Arons uppenbart aktiva roll i avfallet och hans senare särställning som förmedlare mellan Gud och folket. ${ }^{12}$ Förutom otaliga frågor av mer detaljerad karaktär som vi ovan har exemplifierad kan man under ytan förnimma en grundläggande fråga: "Finns det hopp för ett folk som har blandat sig i detta?"

I kalvepisoden har man alltså, vad beträffar framställningen, en icke-uttömmande, fantasieggande text, och vad beträffar innehållet, en text som är känsloladdad och alltid mer eller mindre i spänning med resten av Israels historia och med det bibliska idealet om förbundstrohet. Den är kanske den mest eldfängda texten i hela Gamla testamentet som själv, alldeles utan någon yttre drivkraft, erbjuder möjligheter och kanske rent av lockar till midrashtolkning. Här är samma dynamik verksam som vid vilken annan bibeltext som helst som i någon mån uppfyller de ovan definierade kriterierna. Detta kan förklara en del av den apologetiska tendensen men ändå är det svårt att förklara förekomsten av den stora mängd apologetiskt färgad tolkning, dess speciella frammarsch $i$ ett bestämt historiskt skede samt alla drag i den enbart som frukter av den s.k. rena exegesen.

\section{KALVEPISODEN HOS TIDIGA KRISTNA FÖRFATTARE}

Hos kyrkofäderna används kalvepisoden effektivt som en argumentkälla för polemiken mot synagogan. Många ofta förekommande drag är bekanta redan 
genom Stefanos' tal i Apg 7. Grundidén som sammanbinder Apg 7 med de flesta efterapostoliska kristna tolkningarna är att Israels avfall i det förflutna fortfarande är avgörande för folkets ställning inför Gud och kan fortfarande användas som en grund för bedömning av folkets karaktär. Den apostoliska grunden till den patristiska synen på "den evige juden" kan väl vara Stefanos' ord: "Styvnackade är ni, oomskurna till hjärta och till öron. Alltid gör ni motstånd mot den Heliga Anden, ni som era fäder." (Apg. 7:5r)

Den patristiska antijudiska polemiken med kalvepisoden i fokus kan enkelt indelas i två kategorier: tolkningar vilka I) ser kalvdyrkan som ett bevis på det judiska folkets karaktär samt 2) betonar kalvdyrkans ödesdigra följdverkningar. ${ }^{13}$

Israeliternas kalvdyrkan, trots alla mirakel som de hade fått se, var ett ovedersägligt bevis på det judiska folkets trolösa, otåliga och otacksamma karaktär. ${ }^{14}$ Att avgudadyrkan verkligen var en djupt inrotad benägenhet hos israeliterna framgår av att folket på nytt ägnade sig åt kalvdyrkan under Jerobeams tid ${ }^{15}$ samt att judarna, enligt Efraim Syriern, jublade när de såg oxbilden som Julianus Avfällingen lät prägla på sina mynt. ${ }^{16}$ Kalvepisoden förekommer som en urbild av Israels uppstudsighet och ohörsamhet. I enlighet med argumentationen i Stefanos' tal (Apg 7) uttrycks enligt den patristiska polemiken Israels uppstudsighet efter kalvepisoden speciellt $i$ avvisandet och dödandet av profeter som anklagar Israel för dess synder. ${ }^{17}$ Sin kulmen når upproriskheten i förkastandet av Guds fullkomliga uppenbarelse i Kristus.

(...) och ändå var han (Gud) mottagen med otro av dem som såg dessa tecken. Ty hade de trott på det de fick skåda och höra, skulle de inte ha gjort kalven (...) Jag tror att det som har sagts räcker till att övertyga var och en om att judarnas otro beträffande Jesus är i linje med det som har blivit sagt om detta folk från begynnelsen. (Origenes, Cels 2,74-75)

Kalvdyrkans följdverkningar ansågs vara av två slag: en jordisk börda och en evig förbannelse. Den tvångsmässiga och tunga ceremonial- och renhetslagen är en börda lagd på Israel på grund av dess ohörsamhet vid Sinai. De nya tavlorna är inte förbundets tavlor utan kravbindande ceremonilag.

Men då detta folk (...) förklarade kalven som Gud, i stället för den sanna Guden (...) blev Gud, för att hade blivit otacksamt bemött av dem, arg och kravband dem med band som inte kan lösas upp. (ConstAp 6,20)

Den mest kategoriska formen tar polemiken i påståendet att förbundet mellan Gud och Israel har brutits. Brytandet av förbundet fick sitt uttryck i krossandet av lagens tavlor. Det tydligaste uttrycket för den här tanken dyker upp redan under det första århundradet i Barnabas' brev. 
Men när de hade vänt sig till avgudarna förlorade de förbundet. Ty Herren talar så: "Mose, Mose, stig ned med hast, ty ditt folk, som du har fört ut ur Egypten, har överträrt lagen." Och Mose förstod och kastade de båda tavlorna ur sin händer. Och deras förbund slogs sönder, för att den älskade Jesu förbund i stället skulle inristas i våra hjärtan, genom trons hopp till honom. (Barnabas 4,7$)^{18}$

Har vi Barnabas som ett exempel från den premishnaiska tiden kan vi kanske finna en lämplig avslutning till vår korta sammanfattning i Augustinus' allegoriska tolkning av straffet utfört av Mose. Enligt Augustinus upprättades i drickandet av kalvens stoft en djävulens nattvard.

Det fanns även den här kalven som folket dyrkade $\mathrm{i}$ otro, avfallna, begivna på egyptiernas gudar och förkastande honom som hade befriat dem från slaveri under egyptierna - och i det blev ett stort sakrament instiftat (...) Vad är detta annat än att djävuldyrkarna blir dess kropp? $\left(\right.$ EnPs $_{74, \mathrm{I} 3)^{19}}$

Man kan med skäl ansluta sig Smolar \& Aberbachs konstaterande om att kalvepisoden filtrerad genom patristisk tolkning blev hörnstenen i den medeltida identifikationen av en jude med djävulen. ${ }^{20}$

Som en motvikt till det ovan sagda är det nödvändigt att konstatera att och detta är en viktig aspekt med tanke på vår evaluering av ursprunget till den rabbinska pro-aronitiska attityden - Aron aldrig tadlas i den kristna litteraturen.

\section{KALVEPISODEN UNDER DEN TANNAITISKA PERIODEN}

Iakttagelsen som ovan har tillskrivits I. J. Mandelbaum håller streck, dvs. auktoriteterna bakom de tannaitiska verken accepterar den bibliska textens budskap som sådan, men det betyder inte att vi inte skulle kunna hitta spår av försök att undvika de möjliga stötestenar som finns i berättelsen. Först skall vi ägna några ord till den egentliga exegesen.

I de tannaitiska källorna hänvisas till episoden såsom det mest allvarliga avfallet i Israels historia. ${ }^{21}$ Episoden tjänar också som en illustration av processen från synd till försoning. ${ }^{22}$ Ett exempel: Enligt Sifre Devarim I,9 sade Herren till Israel: "Jag skulle ha kunnat förbise allt som du har gjort men överträdelsen med kalven är värre än de alla andra gärningar.” Bedömningen är otvetydig - avfallets allvar skönmålas inte - men man behöver inte läsa längre än till I,Io för att kunna hitta utvägen ur förtvivlan presenterad av R. Benaja och R. Jose ben Hanina: "Må guldet i locket (כפרת) komma och försona (וכפר) guldet i kalven." 
Att det i tannaitiska källor förekommer mycket material om försoningen tvingar oss inte att återta det som redan har konstaterats om frånvaron av apologi i tannaitiska verk. Försoningen efter avfallet är ett viktigt tema i den tannaitiska exegesen över kalvepisoden, och redan själva ordet försoning implicerar att en överträdelse har ägt rum. De i senare skeden frekventa försöken att relativisera eller negligera ökengenerationens skuld förekommer inte hos tannaitiska rabbiner.

En implicit förutsättning i alla tiders judisk tolkning är övertygelsen att Gud har försonat Israel och Aron med sig. Detta kan utan större problem deduceras ur bibeltextens vittnesbörd också utan hjälp av den rabbinska hermeneutiken. Israels historia som Guds folk fortsätter också efter Sinai och Aron blir utvald till överstepräst. Trots att rabbinerna också kan hävda att kalvdyrkan lämnade sina spår i Israel för all framtid ${ }^{24}$ är försoningen ändå ett odiskutabelt faktum redan i tannaitiska källor. Betraktade mot bakgrunden av bibeltextens någorlunda uppenbara budskap och den ovannämnda utgångspunkten för all judisk tolkning (försoningen) väcker de mångahanda omtolkningarna med en apologetisk prägel som tiden efter tannaiterna för med sig uppmärksamhet. De kan tänkas bära vittne om att utläggarna aldrig kände sig fullt nöjda med de argument som lanserats. De frågorna som bibeltexten gav upphov till ansågs vara i grunden vettiga eftersom all den spänning och skandal som låg $\mathrm{i}$ den bibliska berättelsen inte hade blivit löst trots den uppenbara försoningen. Den bibliska berättelsen försatte Israels folk i ogynnsam dager oberoende av att vandringen som gudsfolk fortsatte. Den visade också Aron i ogynnsam dager oberoende av att han blev smord till överstepräst. Tilläggsargument var därför välkomna.

Innan vi övergår till att åskådliggöra de tilläggsargument som amoraitiska periodens utläggare erbjöd stannar vi för en stund vid det sk. översättningsförbudet som i den explicita halakhans form dyker upp i Mishna. Det är en nödvändig komplettering till den bilden som ovan har tecknats om den tannaitiska perioden.

Den första berättelsen om kalven skall läsas och översättas. Den andra berättelsen skall läsas men inte översättas. (Mishna Megilla 4,10)

Den andra berättelsen om kalven skall läsas men inte översättas.

Vilken är den andra berättelsen om kalven? Från "Och Moses sade till Aron: 'Vad gjorde detta folk mot dig (v.2ra)", ända till "Och Mose såg folket som var lössläppt (v.25a)." Och en vers till: "Och Herren slog folket." (v.35) Om den här saken sade R. Simeon ben Eleazar: "En man har inte rätt att bortförklara sin missgärning (אין ארם רשיי להשיב על הקלקלה) Ty av svaret som Aron gav Mose härleder heretiker sina tolkningar." (Tosefta Megilla 3,36-37) 
Dessa två ställen vittnar om att det under den tannaitiska perioden ändå förekom viljan att $\mathrm{i}$ offentligheten undvika de möjliga stötestenar som finns i den ifrågavarande bibliska berättelsen. Detta fenomen kunde karakteriseras som ett uttryck för en moderat apologetisk attityd, passivt motvärn eller en försiktighetsåtgärd. Samma förbud upprepas i Jerushalmi och Bavli och kommenteras vidare. ${ }^{26}$ Kontexten - de s.k. listorna över förbjudna targumerna i traktaten Megilla i Mishna, Tosefta, Jerushalmi och Bavli ${ }^{27}$ - visar entydigt att med läsandet och översättandet avses den offentliga textläsningen i synagoggudstjänsten och översättandet till folkspråk. Trots olika meningar angående det förbjudna avsnittets omfattning kan man sluta sig till att det problematiska ansågs ligga $\mathrm{i}$ innehållet $\mathrm{i}$ verserna $2 \mathrm{I}-25 .{ }^{28}$ Den andra berättelsen om kalven är avsnittet som innesluter redogörelsen om händelseförloppets gång i Arons egna ord och Moses hårda ord mot Aron. En brännpunkt är v. 24 med Arons fantasieggande svar till Mose.

Jag förhåller mig tveksamt till den reella, praktiska betydelsen från åhörarnas synvinkel av att man inte översatte vissa verser. Om huvuddragen i den bibliska historien i varje fall var bekanta för synagogbesökaren, kan en dylik censur endast ha väckt uppmärksamhet och förvåning hos åhörarna. Man bör kanske se detta förfarande närmast som en principiell försiktighetsåtgärd, kanske även som ett uttryck för fromhet som visas i förhållande till den heliga skriften. Genom att dra bort de delar som kunde ansågs vara misskrediterande för Aron, kunde rabbinerna leva efter den allmänna inomjudiska tendensen att idealisera och försvara Aron. Urvalet av oöversatta verser i targum Neofiti - som är den enda targumtexten som i någon form följer den rabbinska halakhan om översättningsförbudet - däremot tyder på tendensen att hoppa över ställen där Israel förknippas med gudabelätet. Människorna bakom denna targumtext ville kanske på det här sättet enbart visa en ganska långt driven pietet. Den rabbinska traditionen lovade ju nämligen ingenting gott åt den som gjorde sig skyldig till att bringa skam över Israel: "Den Helige, välsignad vare han, finner inget behag i den som nedsvärtar Israel." (Shir haShirim Rabba I,6 (I) $)^{29}$

Ändå var det kanske inte enbart frågan om pietet inför en helig text. Man skall komma ihåg att targumerna, speciellt de palestinska, för det mesta inte var ordagranna översättningar av den hebreiska texten utan utläggande parafraser. Det som rabbinerna var måna om var inte enbart att folket skulle få höra texten på sitt språk, utan också den tolkning som meturgeman kunde ge i sin översättning. ${ }^{30}$ Fruktan för å ena sidan problem med den ordagranna översättningen och å andra sidan för de följder som en okontrollerad frihet för meturgeman att parafrasera texten skulle åstadkomma kommer väl till synes i en utsaga tillskriven R. Juda i Tosefta Megilla 3,4I: "Han som översätter 
versen efter dess form - se, han är en lögnare, och han som gör tillägg - se, han är en hädare." Man kan tänkas ha velat ta kontroll över den vilda tolkning som meturgeman annars kunde inbegripa i sin tolkande översättning. Här kommer speciellt Ex 32,24 in i bilden. Jag ansluter mig till förklaringen erbjuden av D.J. Halperin. Han förklarar det problematiska med v. 24 i kalvepisoden med problemet som merkava-mystiken ställde för de rabbinska auktoriteterna. Guds himmelska vagns (Hes I), merkavas, anknytning till Sinai kan med säkerhet dateras till förkristen tid. ${ }^{31}$ Den här anknytningen öppnade en tidigare osedd värld av tolkningar. Visionen kunde utnyttjas till att belysa det egentliga innehållet $\mathrm{i}$ händelserna vid Sinai. ${ }^{32}$ I den bibliska skildringen av händelserna på Sinai förblev Herren mer eller mindre fördold, medan man genom Hesekiels syn kunde se honom köra på scenen i all sin härlighet. Genom Hesekiels vision kunde man få en rätt insikt i den verkliga härligheten i Guds uppenbarelse på Sinai och en mer detaljerad bild av det som bara i summariska ordalag återges i Ex 19 och 24-32. Enligt en midrash fick israeliterna - trots att de gammaltestamentliga kalvepisodstexterna inte ger någon antydan om det - skåda Guds merkava när han uppenbarade sig på Sinai. Folkets tragiska fel var att det fäste sin uppmärksamhet vid ett av de fyra väsendena och ansåg det vara den form i vilken Gud ville uppenbara sig. ${ }^{33}$

I ljuset av detta var det inget under att israeliterna ville avbilda sin förlossare som en tjur - den hade de ju fătt se när Herren uppenbarade sig. Dessa tankar gav, särskilt om man gick så långt att man förklarade att kalvstoden fick liv av den himmelska tjuren, rabbinerna anledning att ställa sig reserverade till att Ex 32,24 skulle bli "allmän egendom" inom syngagogförsamlingen. I den rabbinska litteraturen kan man möta samma slags motvilja mot associationen mellan guldkalven och merkava-tjuren, då man i Mekilta BeShalla 7 ser R. Aqiva motsätta sig häftigt tanken på att israeliterna vid Sinai skulle ha dyrkat den himmelska oxen.

Genom att förbjuda översättandet av den andra berättelsen om kalven kunde den rabbinska rörelsen șlå två flugor i en smäll - att visa pietet genom att värna Arons ära och att hålla den meturgeman som kanske kände en viss dragning till merkava-mystiken i styr. Det ter sig högst osannolikt att översättningsförbudet skulle har någonting att göra med det kristna bruket av kalvepisoden. Orsaker till halakhan är inomjudiska.

\section{DEN APOLOGETISKA EXEGESENS FRAMMARSCH}

\section{AMORAITISKA KÄLLOR}

Den rabbinska tolkningen trodde sig kunna redan i den gammaltestamentliga texten finna spår av strävan efter att dölja skandalen med kalven..$^{34}$ Detta hade 
alltså skett med Gud som initiativtagare eller åtminstone i samråd med honom. Kanske masoreterna kunde stöda sig på den här gudomliga sanktionen då de gjorde ett medvetet läsfel och lät folket läsa texten i I Kon IO,I9 i formen "och tronens ryggstycke var avrundat upptill" (וראש עגול לפסה מאחריו) medan LXX uppenbarligen hade läst $i$ sin grundtext hänvisningen till ראש) (dvs. egal istället för agol) och därför översätter "tronen hade tju-

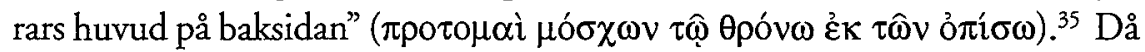
Gud själv är villig att förborga eller undanskaffa det som bringar Israel på skam fast han redan har försonat sig med detta bör vi inte undra om att även senare utläggare ansåg det behövligt. En frammarsch av apologetiskt präglad midrash träffas i amoraitiska källorna. ${ }^{36}$ Det sammanbindande draget i tolkningarna är att av skäl som inte kan läsas i bibeltexten - eller åtminstone inte förnimmas utan hjälp av den rabbinska exegesen - är Israel inte helt, eller alls, ansvarigt för synden. Detsamma gäller ännu i högre grad Aron: Folket, åtminstone en del av det, blev ju straffat men Aron fick prästadömet som en belöning för sina rättrådiga intentioner.

Jag redogör i korthet på vilka håll den apologetiska tolkningen hittar förmildrande omständigheter. Jag tror att förekomsten av dessa midrasher är mer upplysande än deras egentliga innehåll och därför vågar jag begränsa mig till några enstaka exempel.

Israeliterna kan beskrivas som offer: de lät sig vilseledas. Då den fyrtionde dagen hade kommit och Mose hade inte kommit kom Satan och visade dem den döde Mose i en vision. ${ }^{37}$ Israeliterna berättas även ha fallit offer för villfarelse och blivit övertygade om gudabelätets gudomlighet då de fick se kalven röra sig. Det här fenomenet förorsakades antingen av Satan eller av ickeisraelitiska element bland folket ${ }^{38}$ Det berättas också att Israel var inte huvudansvarigt för kalven. De som kom med sin fordran till Aron var pseudokonvertiter som hade förts upp ur Egypten med Israel (se Ex I2,38) ${ }^{39}$ Den apologetiska exegesen flyttar sig till en ny nivå i och med att från förklaringar som fäster vid de yttre faktorerna vänder man blicken på Guds andel i avfallet. Gud själv åtar sig ansvaret för Israels missgärning. R. Akiva sätter i Guds mun frågan och bekännelsen: "Vem drev er till att göra en gud av guld? Jag , jag gav er mycket guld." 40 Herren beskyllas också för att han lät sitt folk vara så länge i fångenskap i Egypten, avgudadyrkans näste. ${ }^{41}$ Israel liknas även med ett nyfött barn som inte har fătt undervisning i Lagen och därför inte kan anses stå till svars. ${ }^{42}$ Den här typens apologi kulminerar då hela händelsen ges en ny färg. Den allvarliga överträdelsen kan uppfattas som ett exempel som Gud ville ge med syfte att vittna om nådens oöverträffliga makt för världens folk. R. Josua ben Levi sade: "Israel gjorde kalven endast för att öppna dörren för botfärdiga." 43 Som ett slags crescendo i rabbinska försvaret av Israels ära efter alla dessa ovan beskrivna bortförklaringar - står det material som mycket 
rättlinjigt grundar Israels fortbestånd som ett förbundsfolk på Guds orubbliga förbundstrohet. ${ }^{44}$

Inom dessa tolkningar kan man ofta förnimma en viss spänning mellan det faktum att Israel i bibeltexten beskylls hårt och viljan att bortförklara åtminstone en del av skulden. En mera entydig bild făr man genom den rabbinska attityden till Aron. ${ }^{45}$ Det tycks ha varit någorlunda klart för auktoriteterna bakom alla tidiga judiska källor hur man bör förstå och förklara Arons andel och ansvar i händelseförloppet. Man kan inte undvika intrycket att Arons ära är det mest centrala bekymret för den tidiga judendomen (mest accentuerad är den här tendensen redan under det första århundradet hos PseudoFilon), medan det i förhållande till folkets beteende förekommer $i$ viss mån svävande uppfattningar. Att bevara det andliga ledarskapet obefläckat är den främsta angelägenheten, medan folket kan tänkas förtjäna klander.

Fördjupandet i den apologetiska exegesen av kalvepisoden leder läsaren inte till några oomtvistliga slutsatser beträffande upphovet till den. Enligt min mening är den största delen av den här tolkning till sin form sådan att den helt enkelt har väckts i mötet med den laddade texten själv. Den vill svara på de kritiska frågorna som ovan beskrevs. I kalvepisoden hittar man samlat praktiskt taget alla de karakteristiska drag vilka även var och en enskilt skulle räcka till för att framkalla midrashtolkning (Vermes' kategori "pure exegesis"). Likväl kan man dock tänka sig att fastän själva midrashiska tolkningar av detaljer i den bibliska episoden hade spirats upp i mötet med texten har dessa frågeställningar på ett särskilt sätt aktualiserats i och med att man har observerat episodens eldfängdhet genom användningen av den i kyrkans polemik. Kyrkan påstod ju att den i Israels ställe trätt in i det nya Förbundet. Med största sannolikhet kan den kristna polemiken tänkas skymta i bakgrunden $\mathrm{i}$ midrashgrenen bevarad i Pesikta deRav Kahana 2,I och i det gemensamma stoffet i Pesikta deRav KahanaK 9,7; Wajjikra Rabba 27,8 och TanhumaB Emor I5.

De säger till Israel: "Ett folk som vid Sinaiberget hörde från sin Guds mun: 'Du skall inga andra gudar ha vid sidan av mig.'(Ex 20,3) och efter fyrtio dagar sade om en kalv: 'Detta är din Gud, Israel.' (Ex 32,4) - finns det en frälsning för detta (folk)?' Det finns ingen frälsning för honom hos Gud. Sela.' (Ps 3,3)" Israel sade: "Och (fastän) du, Herre, förenar dig med dem och skriver $\mathrm{i}$ din Tora och säger: 'Den som offrar åt andra gudar (än åt Herren ensam, han skall tillspilloges) (Ex 22,20), (är du ändå) 'en sköld för mig' (Ps 3,4) som vi får på grund av våra fäders förtjänster. (...) I stället för det som vi förtjänade - avslitandet av huvudet gav du oss upplyftandet av (vårt) huvud genom Moses hand och sade: 'När du lyfter upp Israels barns huvud.'” (Pesikta deRav Kahana 2,I) 
Varför fann han det skäligt att sätta oxen såsom det första av alla offer? R. Levi sade: "En förnäm kvinna bragtes i vanrykte för (sitt förhållande med) en av stormännen $i$ riket. Och kungen undersökte ryktena men fann ingenting i dem. Vad gjorde [WaR: kungen]? Han ordnade en [PRK: stor] fest och placerade denne man på första platsen bland gästerna. Varför allt detta? För att visa att kungen hade prövat ryktena och ingenting funnit i dem. På samma sätt hånar världens folk (העולם אומות) Israel och säger till dem: 'Ni gjorde guldkalven!' Den Helige, vare han välsignad, prövade ryktena och fann ingenting i dem. Därför sattes oxen såsom det första av alla offer (såsom det sägs:) 'en oxe eller ett får eller en get' (Lev 22,27)." (Pesikta deRavKahana 9,7-8. Wajjikra Rabba 27,8. TanhumaB Emor 15)

I dessa ställen hänvisas till "världens folk" som ifrågasätter Guds ynnest gentemot sitt folk p.g.a. kalvepisoden. Kärnan i dessa texter var antingen Herrens vederläggande av hedningarnas beskyllningar eller Herrens orubbliga kärlek till sitt folk trots motsatta påståenden från världens folk. Frågor som den kristna ersättningsteologin ställer kunde lätt förnimmas skymta i bakgrunden även till b Ber 32b där Herren med kraft försäkrar att han enbart ser Israels helhjärtade underkastelse till Herren vid Sinai och inte alls dess villfarelse med kalven. Något oemotsägligt samband kan inte påvisas men i dessa fall är korrelationen med den kristna polemikens centrala tema iögonenfallande. Beträffande den mångformiga apologin för Aron bör man däremot inte räkna med impulsen från kyrkans polemik ty, såsom ovan har konstaterats, var värnandet av Arons ära en gemensam angelägenhet för den judiska och kristna tolkningstraditionen. Därtill kan man konstatera att såväl den pro-aronitiska apologetiska tolkningen som traditionen av hemlighållandet - att undvika det problematiska genom att förtiga - har förekommit i sammanhang där påverkan av kyrkans närvaro inte skymtar i bakgrunden. Kan man då överhuvudtaget peka på någonting i tolkningar av kalvepisoden och påstå att detta har förorsakats av konfrontationen med kyrkan? Ja - man kan i enstaka fall peka på teman i utläggningen, såsom det gjordes ovan, men först och främst skall man fästa sin uppmärksamhet vid förekomsten, dvs. vid kontrasten mellan olika perioder.

\section{VÄGEN TILL EN SANNINGSENLIG BEDÖMNING}

Det som de rabbinska källorna direkt berättar om konfrontation med yttre krafter är knappt. Man möter dock detaljer och drag i den rabbinska litteraturen som är svåra att förklara ifall man inte räknar med kristendomens närvaro 
och kunskap om den hos rabbinerna. Den här vägen att närma sig problematiken kan alltså inte bedömas som gagnlös men problemen - den oundvikliga inskränkningen till vissa enstaka texter och deras möjligen fiktiva yta - kvarstår. En mer lovande riktning har utstakats bl.a. av A.F. Segal. Man fokuserar på omfattande motiv som kan anses återspegla centrala debattämnen i konfrontationen med kyrkan eller ge antydningar om doktriner och praxis som skilde en heretisk grupp från den rabbinska skolan. Ett sådant tema är t.ex. den rabbinska debatten om två krafter i himmelen, som har utretts grundligt av Segal. En tillämpning av den här vägen till ämnet som här behandlas förverkligas t.ex. i det att vi inte fäster vår uppmärksamhet enbart på uttrycket "världens folk" och stannar vid det - och frågar huruvida det kan innebära en antydan om kristna eller inte ${ }^{46}-$ utan i stället utvidgar perspektivet och sätter uttryck för kyrkans teologi om judarnas förlorade förbund och uttryck för judisk teologi om förbundets fortbestånd mot varandra och märker att i vissa fall korrelerar de bättre än i andra.

Ett steg vidare på den här linjen från fokuserandet på enstaka teologiska motiv är betraktandet av förändringar i stora teologiska motiv som indikationer på yttre påverkan. Den här vägen representeras av Neusner när han kartlägger judisk-kristna relationer på tre- och fyrahundratalen och söker belägg för kristet inflytande i de rabbinska källorna från denna tid. I Judaism in the Matrix of Christianity ${ }^{47}$ belyser Neusner den kontrast som kan märkas mellan den skriftliga produktionens period från Mishna över ett hundra år framåt och perioden då exegetiska kompilationer efter Tosefta kom till, fr.o.m. fjärde århundrade. Man kan visa att en djuptgående förändring i synen på Rom, Messias och Tora sker. Den här kontrasteringen leder honom till den preliminära slutsatsen att man kan förutsätta kristendomen bakom utformandet av den judendomen som vi nu kallar för den normativa. I Judaism and Christianity in the Age of Constantine $e^{48}$ övergår Neusner till att söka bekräftelse för sin teori om det som han kallar för den första konfrontationen. Han jämför systematiskt tre teman hos 300-talets kytkofäder samt i Jerushalmi, Bereshit Rabba och Wajjikra Rabba från ungefär samma period ${ }^{49}$ och kommer till slutsatsen att man hos den judiska parten finner direkta svar på den kristna triumferande teologin och den politiska triumfen som 30o-talet förde med sig. ${ }^{50}$

Då 300-talets politisk-religiösa revolution (från toleransediktet år 3 I2 till Teodosius' edikt år 387) förknippad med den triumferande kristna teologin uppenbarligen framkallade omformulering av vissa gamla idéer i judisk teologi, såsom Neusner påvisar, är det inte långsökt att anta att samma period och samma samverkan av maktpolitiska och teologiska faktorer även framkallat en ny inställning till den skamligaste gammaltestamentliga texten.

Eftersom stödjandet på enskilda midrashers innehåll är ett mindre frukt- 
bart sätt att tackla problemet, lăter vi, som Neusner säger, "contrast tell the tale". ${ }^{51}$ Frammarschen av apologetisk midrash i den amoraitiska periodens källor ger en antydan om hur förbryllade judarna var av den historiska omvälvningen på trehundratalet. Det som judendomen konfronterades med var ett nytt slags kristendom, nu på sitt segertåg i verkligheten - inte bara i teologisk retorik som hos de tidigare kyrkofäderna. Med andra ord: aspekt som i den rabbinska betraktarens ögon utan tvekan ger eftertryck åt kyrkans triumferande teologi och de bekanta påståendena om det gamla förbundets upphävande är kyrkans verkliga, yttre triumf. Den - och inte själva polemiken tvingar rabbinerna till en reaktion.

\section{Slutsatser}

Jag bedömer konfrontationen med det problematiska i texten - m.a.o. kalvepisodens inre potential att väcka spekulation - som den viktigaste faktorn bakom uppkomsten av den tidiga judiska apologetiska tolkningen av episoden. I rabbinska apologetiska exegesen ser man en tudelad fokus: bekymmer om Israels och Arons ära. Motståndet mot merkava-tolkningen öppnar ett tredje apologetiskt motiv. Förutom att man ville försvara Arons och Israels ära ville den rabbinska traditionen även försvara den ortodoxa utläggningen av Skriften.

Den kristna polemiken spelar dock en roll i uppkomst av den judiska apologin beträffande kalvepisoden: dess förekomst är bekant för rabbinerna och den blir en aktuell angelägenhet i och med den konstantinska omvälvningen. Jag utnyttjar audience criticism / konfrontationskritikens infallsvinkel för att åskådliggöra den enorma laddning som ligger i trehundratalets omvälvning och i det nya som den här vändpunkten förde med sig genom att låna vokabulären i M. Callaways definition, som citerades i inledningsavsnittet. Spänningen koncentrerar sig kring det centrala begreppet "Förbund". Enligt Callaway närmar "audience criticism" sitt objekt, midrashens Sitz im Leben och adressater, genom att betrakta midrashen utifrån en bakgrund som utgörs av "concerns of the community, recent events which might be on the minds of the people, problems which were disturbing the community, and to some extent, values which were presupposed by the community." Tillämpad på tidsåldern som producerade eller snarare, aktualiserade, den stora mängden av apologetisk midrash gällande kalvepisoden, ser teoremet ut så här. Det fundamentala värdet ("values which were presupposed") är Förbundet, en fundamental anledning till bekymmer ("concerns of the community") är Förbundets fortbestånd, den fundamentala händelsen ("recent events") som har 
drabbat samfundet är den uppenbara triumfen för dem som påstår sig ha övertagit Förbundet från judarna och problemet som plågar samfundet ("problems disturbing the community") är de oemotsägliga bevisen som tiden ger för att Förbundet har tagits från judarna.

\section{Noter}

I. Detta fenomen kommer väl till synes bl.a. i nutida Europas uppgörelse med holocausttiden. Exempel vilka torde vara onödiga i detta sammanhang är många från de senaste åren.

2. "applied exegesis", "pure exegesis". Vermes, 202-203.

3. Kortfattat: "konfrontationskritik" är identisk med "audience, criticism" hos J. A. Sanders. Sitt sätt att närma texter karakteriserar Sanders själv så här: "(...) seeing the contemporization of an ancient tradition in the light of the need of the community which recalled, and reflected upon, the tradition." Citerad i Callaway, II. Callaways - elev till Sanders - definition lyder: "(...) it tries to reconstruct the presuppositions of the writer or speaker in addressing the community. These would include, for example, concerns of the community, recent events which might be on the minds of the people, problems which were disturbing the community, and to some extent, values which were presupposed by the community." Ibid. Begreppet "audience criticism" dock å ena sidan leder tankarna främst till teatervärlden och å andra sidan är hänvisningen till publik i varje fall för snäv. Det är inte enbart åhörarna $\mathrm{i}$ kött och blod som kan kräva svar. Konfrontationens aspekt däremot samlar ihop såväl faktiska åhörare som mer abstrakta utmaningar.

4. Trots rubriken intar den apologetiska tolkningen av kalvepisoden en huvudroll i Marmorsteins studie.

5. Ett typiskt exempel gäller midrashen i Shemot Rabba 3I,Io där Guds eviga kärlek till sitt folk betonas. Marmorstein drar slutsatsen: "The author of this homily must have faced missionaries in Galilee, who propagated the Gospel of Israel's rejection (...)" Marmorstein, 238. Beträffande den kristna teologin kommer författaren likaså med ganska förenklade påstånden, t.ex.: "Paul and Barnabas could not find words strong enough to condemn the law. The law was given as a sign and as punishment for Israel's golden calf." Marmorstein, 240. Inte ett enda ställe där Paulus skulle behandla lagen som ett straff för kalvdyrkan är mig bekant.

6. Smolar \& Aberbach, Ior.

7. Temat har jag behandlat utförligare i licentiatavhandlingen Guldkalven. Den tidiga judendomen konfronteras med den pinsamma episoden. (Åbo, 1999.) En doktorsavhandling med samma temat är under arbete.

8. Med tannaitiska verk avser Mandelbaum de textsamlingar som innehåller enbart traditioner tillskrivna tannaitiska rabbiner Mishna, Tosefta, Mekilta, Mekilta deRabbi Simeon ben Johai, Sifra, Sifre Bamidbar, Sifre Zuta, Sifre Devarim och Avot deRabbi Natan. Detta betyder alltså inte nödvändigtvis att de skulle förmedla information om den tannaitiska tiden utan de bara innehåller de äldsta traditionerna som är tillskrivna tannaitiska auktoriteter. Ibid., 220.

9. Verket heter Liber Antiquitatum Biblicarum. Om kalvepisoden i det, se Begg.

Io. Vermes, 203.

II. Detta betyder inte att den rabbinska midrashen inte skulle ha kunnat hitta även detaljer som är svåra att förena med varandra eller med kontexten: se t.ex. spänningen 
mellan Ex 32,4 och 24 eller mellan Ex 32,20 och Deut 9,21.

12. Ett bra exempel på hur den här spänningen har bekymrat senare generationer finner man i Jehuda Halevis (Kuzari 1,97) långa svar till en hednisk konung som undrar hur judarnas medfödda moraliska upphöjdhet går att kombinera med kalvdyrkan.

13. Sammanfattade framställningar av attityder mot judarna hos de i det här sammanhanget aktuella kristna författarna finns i Schreckenberg, I7Iff.

14. Justinos, Dial 19,5; 102,6; I32,r. Tertullianus, Pat 5,22; Marc 2,18. ConstAp 6.4,20. Irenaeus, Haer 4,3. Origenes, Cels 2,74. Justinos (Dial 19,5; 132,I) kompletterar sina beskyllningar med påminnelsen om att judarna också dyrkade stjärnor (jfr. Apg 7,42) och offrade sina barn åt Molok.

I5. Tertullianus, Iud I. Se även hänvisningen till Justinos' Dial 19,5; 132,x i föregående not.

16. Fyra hymner om Julianus Avfällingen I, I6-I7.

17. T.ex. Lactantius' Inst 4 samt II-I2 erbjuder utmärkta exempel på kyrkofädernas intensiva bruk av profeternas anklagande utsagor om Israel.

I8. Andréns översättning i De apostoliska fäderna, 144. Se även Barnabas I4,4 och Efraim Syriern, Diat 20,35.

19. Se även EnPs 36,26 och 62,5.

20. Smolar \& Aberbach, Ior.

21. Mandelbaum analyserar Tosefta Shabbat I,I6; Sifre Devarim 1,9 och 319,3; Mekilta Bahodesh 2 och 9 samt Sifre Bamidbar 1.ro,2-3. Mandelbaum, 208-2x3.

22. Mandelbaum analyserar Sifra Zav (Mekilta deMiluim I,I) och Shemini I,3-5.8. Mandelbaum, 213-2I8.

23. "Nådastol" enligt 1917 års svensk översättning.

24. "R. Isak sade: 'Det skall inte bli något straff för världen som inte innebär en smula från den första kalven." (Bavli Sanhedrin IO2a)

25. Meningen är svårbegriplig. En alternativ tolkande översättning kunde vara: "En man bör inte upprepa det onda." (= påminna om synden som begåtts).

26. Jerushalmi Megilla $75 \mathrm{c}$ och Bavli Megilla 25b. Genom belägg i targum Neofiti som återger verserna $\mathrm{I}, 4,8,19,20,23,24,3 \mathrm{I}$ och 35 eller delar av dessa oöversatta samt $\mathrm{i}$ masoretiska noter till targum Onkelos vilka ger handledning till användaren i det rätta bruket av targumen (Se Klein, 88-89.) kan man dra den slutsatsen att ett översättningsförbud, åtminstone i viss mån likartat med den rabbinska halakhan i frågan, även har iakttagits i synagogan.

27. Se speciellt studierna av Alexander och Klein.

28. Enligt Tosefta och en utsaga tillskriven R. Aha i Jerushalmi även v. 35 .

29. Se även Bavli Pesahim $87 \mathrm{~b}$ och Jevamot $49 \mathrm{~b}$.

30. Alexander, 182 .

3I. Halperin 1988, 38-62.449. Den tendentiösa LXX-översättningen vid Hes 1,7 som stryker kalven från merkava-synen tyder på detta.Tydlig och t.o.m. självklar för var och en som besökte synagogan blev anknytningen genom att merkava-texten under Shavuot-festen fick fungera som haftara till Ex 19,rff. (b Meg 3ra.) Utsagans tannaitiska ursprungsbeteckning är förstås tvivelaktig. För det äldsta belägget på att Toraläsningen följs av en tematiskt förknippad text ur profeterna, se Apg. 13,15.

32. Merkava-synens anknytning till Sinai-uppenbarelsen observerades redan för länge sedan av åtminstone E.E. Urbach och S. Lieberman. Halperin 1980, 54 och 1988 , I6. Systematiskt har frågan behandlats såvitt jag vet först av Halperin i de omnämnda verken.

33. Tanhuma Ki-Tissa 2I. Shemot Rabba 42,5.43,8.

34. I utsagan "När en tjur eller ett får eller en get har blivit född (...)" (Lev 22,27), hade uttrycket kalv (עגל) som naturligt skulle passa in i sammanhanget med avsikt ersatts med 
tjur (שר) eftersom Toran gärna undviker onödiga påminnelser om guldkalven. (W/ajjikra Rabba 27,3; Pesikta deRav Kahana 9) I samma midrash finner man traditionen om att seraferna i Jesajas syn (Jes 6,2) hade givits tre par vingar för att de med ett par kunde undanskymma sina fötter vilka enligt Hes I,7 liknade kalvens hov. Den rabbinska traditionen tillskrev profeten Hesekiel en vädjan till Gud om att tjuren i den himmelska vagnen (Hes $\mathrm{I}, \mathrm{IO}$ ) skulle bytas ut till en kerub och något senare $\mathrm{i}$ bibeltexten kan rabbinerna hitta bekräftelsen på att så faktiskt hände (se Hes IO,I4). Argument i Hesekiels antagna vädjan är att "åklagaren (dvs. tjuren som påminner om folkets avfall) skulle bli försvarare" (Bavli Rosh haShana 26a, Hagiga I3b). På samma sätt hade Guds befallning om att prästen på Jom haKippur skall klä på sig "en helig livklädnad av linne" (Lev I6,4) i stället för den vanliga guldbrokaden, sin bakgrund i oviljan att onödigt påminna om kalvepisoden. I samma text förklaras det också att shofar för Rosh Hashana inte skall framställas av kohorn ty "åklagaren kan inte bli försvarare”. Guld och kohorn är åklagare. De påminner Gud i onödan om folkets olydnad. I ljuset av detta kunde man med glimten i ögonvrån fråga huruvida det nu alls är lämpligt att en av de nya svenska bibelutgåvorna marknadsförs i dagstidningar med pärmar av kaluskinn...

35. Den här uppfattningen har omfattats av de flesta forskarna under vårt århundrade och har utan vidare anmärkningar även upptagits i flera översättningar. Jfr. dock Noth, 204. Både i Aquila och targum Jonatan till Hes I,7 kan samma förändring från עגל till עוגל hittas och såsom ovan har påpekats har även LXX-översättarna vid samma text, eller tidigare tradenter av den hebreiska texten antagligen gjort en avsiktlig förändring från "fötterna på en kalv" till "bevingade fötter". Detta har behandlats bl.a. i Halperin 1988, 60 .

36. En amoraitiskt verk blir här enkelt definierat genom en hänvisning till not 8 . Med amoraitiska avses de talmudperiodens källor som inte är uppräknade i den. Praktiskt taget är det då frågan om midrasherna fr.o.m. 300-talet samt Jerushalmi och Bavli.

37. Bavli Shabbat 89a. TanhumaB Kị-Tissa 13. Targum Pseudo-Jonatan Ex 32,I. Traditionen om Moses fördröjda återkomst förekommer även $\mathrm{i}$ andra midrasher.

38. Shir haShirim Rabba 1,9. Tanhuma Ki-Tissa 19. Targum Pseudo-Jonatan Ex 32,22.24.

39. Pesikta deRav Kahana 9,7-8. Wajjikra Rabba 27,8. Tanhuma Ki-Tissa 19. Shemot Rabba 42,6. 43,7. 46,4.

40. Tosefta Kippurim 4,I4 (den enda apologetiska exegesen i en tannaitisk källa!). Jerushalmi Joma $45 \mathrm{c}$. Bavli Joma $86 \mathrm{~b}$, Berakhot 32a, Sanhedrin roza. Berakhot $9 \mathrm{~b}$ informerar därtill att israeliterna var ovilliga att ta emot de ymniga rikedomarna från egyptierna men det var Herren som fordrade detta.

4r. Devarim Rabba 3,17. Shemot Rabba 43,7.

42. Wajjikra Rabba 1,yo. Shir haShirim Rabba 2,3.3,4. 8,2. Se även Shemot Rabba 43,I.

43. Bavli Avoda Zara 4b-5a.

44. Pesikta deRav Kahana 2,I. Bavli Berakhot 32a. Shemot Rabba 33,2.

45. Några exempel utgående från Wajjikra Rabba Io,3: Ex 32,5 bör uppfattas i betydelsen: "Aron blev rädd när han såg slaktandet", dvs. Hurs död i folkets händer. Ändå var Aron inte rädd för sin egen död, utan för folkets öde om det skulle döda sin präst. Aron beslöt att göra arbetet själv så att detta skulle ta så länge att Mose hinner återvända. Hans intention var också att kunna helga altaret åt Herren. Han t.o.m. ansåg det bättre att påta sig skulden för villfarelsen och inte låta folket befläcka sig. För dessa åtgärder och ädla intentioner fick Aron prästerskapet som belöning.

46. Såvitt jag kan bedöma används det aldrig i ett sammanhang där det entydigt skulle tyda på kristna.

47. Neusner 1986 .

48. Neusner I987a. 
49. Uppfattningen om historien hos Eusebius och i Bereshit Rabba, idén om Messias hos Krysostomos och i Jerushalmi samt uppfattningen om Israel hos Afrahat och i Wajjikra RabbaR och Bereshit Rabba.

5o. "Christianity's explicit claims, now validated in world-shaking events of the age, demanded a reply. The Sages (...) provided it." Neusner 1987b, I2I.

SI. "Did the sages say these things in order to answer the challenge of Christianity. No one can claim they did. We cannot speculate on motive since we have no evidence by which to test our speculation. All we can do is to point to the contrast between the sages' system as revealed in writings closed in the later second and third century (...) and the system that emerged in the writings of the later fourth and fifth centuries. The contrast tells the tale." Neusner 1986, X. I987b, 4I

\section{LITTERATUR}

Alexander, Philip S., 1976. "The rabbinic lists of forbidden targumim" i: JJS, vol 27, I77-I9r.

De apostoliska fäderna, 1979. De apostoliska fäderna i svensk översättning. Inledning, översättning och förklaring av O. Andrén, Stockholm.

Begg, Christopher T., 1996. "The golden calf episode according to Pseudo-Philo" i: M. Vervenne (red.), Studies in the book of Exodus. Redaction - Reception - Interpretation. Bibliotheca Ephemeridium theologicarum lovanensium, vol I26, Leuven, 577-594.

Callaway, Mary, I986. Sing, o barren one. A study in the comparative midrash. SBL Dissertation Series, vol 9r, Atlanta.

Halperin, David J., 1980. The Merkabah in rabbinic literature. American Oriental Series, vol 62, New Haven.

Halperin, David J., 1988. The faces of the chariot. Early Jewish responses to Ezekiel's vision. Texte und studien zum antiken Judentum, hrsg. von $M$. Hengel $\&$ P. Schäfer, vol I6, Tübingen.

Klein, Michael L., I988. "Not to be translated in public - לא מתרגם בציבורא" i: JJS, vol 39, 80-9I.

Mandelbaum, Irving J., I990. "Tannaitic exegesis of the golden calf episode" i: Ph. R. Davies, R.T. White (red.) A tribute to Geza Vermes. Essays on Jewish and Christian literature and history, Sheffield, 207-223.

Marmorstein, Arthur, 1935. "Judaism and Christianity in the middle of the third century" i: HUCA, vol Io, 223-263.

Neusner, Jacob, 1986. Judaism in the matrix of Christianity. Philadelphia.

Neusner, Jacob 1987a. Judaism and Christianity in the age of Constantine. History, messiah, Israel, and the initial confrontation. Chicago studies in the history of Judaism. Chicago.

Neusner, Jacob, 1987b. Self-fulfilling prophecy. Exile and return in the history of Judaism. Boston.

Noth, Martin, 1968. Könige. I. Teilband. Biblischer Kommentar zum Alten Testament, vol 9.1, Neukirchen-Vluyn.

Schreckenberg, Heinz, 1999. Die christlichen Adversus-Judaeos-Texte und ibr literarisches und historisches Umfeld (I.-II. Jh.). 4., überarbeitete und ergänzte Auflage. Europäische Hochschulschriften, serie 23, vol 172, Frankfurt am Main et al. 
Segal, Alan F., 1977. Two powers in heaven. Early Rabbinic reports about Christianity and Gnosticism. Studies in Judaism in Late Antiquity, vol 25, Leiden.

Smolar, Leivy \& Aberbach, Moshe, 1968. "The golden calf episode in postbiblical literature" i: HUCA, vol 39, 9I-II6.

Vermes, Geza, I970. "Bible and Midrash: Early Old Testament exegesis" i: Cambridge History of the Bible, vol I, I99--23I.

\section{Summary}

This article focuses on the Rabbinic reaction to the Sinaitic golden calf episode. The episode is a source of embarrassment to Israel as it describes the major fall of the elected people, connecting her with idolatry. From the point of view of the early church, the episode gives indisputable proof of the idolatrous nature of the Jewish people and of the fact that the Lord eternally has rejected this rebellious nation. This delicacy of the Biblical motive at hand and the fervent use of it by the early church gives the episode its significance in the study of the early Jewish-Christian controversy. The most comprehensive investigation of the theme so far, by Smolar and Aberbach, has indisputably shown that the so-called apologetical attitude is dominant among the interpretations found in early Judaic sources. The investigation, however, leaves us in the half-way due to its ignorance of the varying historical periods represented within the 600 years of Talmudic era. The intriguing results of the brief study of Mandelbaum takes us a considerable step further. It shows that the apologetical exegesis is absent from the Tannaitic sources, which in turn leads us to search for an explanation for its appearance in the later sources. The claim of J. Neusner that the upheaval of the Constantinian religious-political revolution in the 4 th century introduced a change in many central aspects of the Jewish theology, forms the basis of my thesis: The upheaval also introduced a change in the Rabbinic reaction to the golden calf episode so closely related with the theology of election. There now begins the era of rich apologetical interpretation of the golden calf episode. In Neusner's words, the contrast with the previous centuries tells the tale. This change can best be explained by the co-operation of the Christian polemic and the new historical setting in which the synagogue had to encounter the now powerful church. Among the Amoraitic apologetically coloured interpretations there are only a couple of texts with any kind of hints of being reactions to the Christian polemic. What can be stated is that all the apologetical material could be the product of inner-Judaic midrashic activity, which in Vermes' vocabulary may be called pure exegesis, but that the growth of this attitude is very probably the result of the political triumph of the church. 